UDC [624.014.2:620.193].001.5

Ahmad Rahbar-Ranji, Assoc.Prof.

Amirkabir University of Technology, 424 Hafez Ave., 15914 Tehran, Iran; e-mail: rahbar@aut.ac.ir

\title{
ELASTIC TRIPPING ANALYSIS OF CORRODED FLAT-BAR STIFFENERS
}

\begin{abstract}
Ахмад Рахбар-Ранжі. Аналіз пружного поздовжнього вигину з крученням плоских ребер жорсткості. Повздовжній вигин $з$ крученням ребер жорсткості є одним з видів втрати стійкості корабельних підкріплених пластин, що може швидко призвести до їх катастрофічного руйнування. Втрата товщини полотна і фланця через корозію призводить до зменшення пружної міцності ребер жорсткості. Зазвичай вважається, що стоншення матеріалу в результаті корозії відбувається рівномірно, однак реальна кородована пластина має шорсткувату поверхню, отже, для оцінки залишкової міцності кородованої конструкції необхідний набагато більш високий рівень точності. Показано, що питання міцності проіржавілих пластин 3 шорсткою поверхнею недостатньо досліджене, особливо в залежності від ступеня корозії. Для аналізу пружної напруги при поздовжньому вигині 3 крученням сталевих плоских пластин, підданих корозії з обох сторін і які мають шорсткувату поверхню, використано метод скінченних елементів. При порівнянні отриманих результатів з величиною пружної обертаючої сили для випадку плоских стрижнів в припущенні рівномірного стоншування матеріалу пропонується понижуючий коефіцієнт.

Ключові слова: кородований сталевий лист, поздовжній вигин з крученням, метод скінченних елементів, шорсткувата поверхня.

Ahmad Rahbar-Ranji. Elastic tripping analysis of corroded flat-bar stiffeners. Tripping of stiffeners is one of the buckling modes of stiffened panel which could rapidly lead to its catastrophic failure. Loss of thickness in web and flange due to corrosion reduces elastic buckling strength of stiffeners. It is common practice to assume a uniform thickness reduction for general corrosion. Since the real corroded plate has rough surfaces, to estimate the remaining strength of corroded structures, typically a much higher level of accuracy is required. There is a little study on strength analysis of corroded plates with rough surface especially as a function of corrosion degrees. The aim of present work is to analyze elastic tripping stress of flat bar stiffeners with both-sided corroded surfaces. Undulated surfaces are generated based on the power spectrum of the corroded surface. Elastic tripping stress is calculated using ANSYS code. Finite elements method is employed to analyze elastic tripping stress of corroded steel flat bars with both sided rough surfaces. Comparing the results with elastic tripping strength of corroded flat bars with uniform thickness, a reduction factor is proposed. It is found that reduction factor of buckling strength by uniform thickness assumption is overestimated.

Keywords: corroded steel plate, tripping, FEM, rough surface.
\end{abstract}

Introduction. Deterioration of aged structures due to corrosion is a common problem in steel ships. For the structural safety assessment of corroded structures, residual strength should be determined as a function of time to plan repairs and replacement. Two main corrosion mechanisms, namely, general corrosion and pitting corrosion are recognized. Pitting is localized corrosion in the form of deep holes and general corrosion which occurs in the relatively larger area is due to coalescence of pits.

Many research works are devoted to residual strength analysis of corroded structures. Nakai et al. [1] have performed a series of nonlinear FEA for plates with pit corrosion subjected to in-plane compressive load and bending moments. Jiang and Guedes-Soares [2] and Huang et al. [3] have studied the ultimate strength of pitted plates under biaxial compression using nonlinear FEA approach Wang et al. [4] have reported strength reduction of corroded deck plate in 20 years old ships under uniform long itudinal compression. They quoted that for single hull tanker strength reduces by about $7 \%$ while for double hull tanker - by $14 \%$.

Significant relevant works have been performed in the area of residual strength evaluation of corroded structures. However, a limited number of research works are investigated time-dependent surface geometries of plates due to corrosion. The actual thickness distribution of corroded plate would be time dependent variable and should be expressed as a function of corrosion degree. Strength analysis of such plate could yield some acceptance criteria to assist surveyors or designers in repairs and replacement planning. Rahbar-Ranji [5] has proposed a spectrum for random simulation of the geometry of corroded surface based on the mean and standard deviation of thickness diminution. Rahbar-Ranji [6...9] has used this spectrum to analyze plastic collapse load, ultimate strength, shear buckling strength and elastic buckling strength of corroded plates with irregular surfaces. He has 
concluded that though one-sided corroded plate has maximum reduction of plastic collapse load, and buckling strength of one-sided and both-sided corroded plate are the same.

The aim of present work is to analyze elastic tripping stress of flat bar (FB) stiffeners with bothsided corroded surfaces. Undulated surfaces are generated based on the power spectrum of the corroded surface. Elastic tripping stress is calculated using ANSYS code (version 5.6). A reduction factor is introduced for a quick estimation of elastic buckling strength of corroded FB as a function of corrosion degree which could assist surveyors to make decisions.

\section{Materials and Methods.}

Geometry of corroded surface. Steel plate that has been exposed to corrosive environments exhibits a characteristically irregular surface and this one would expect that the thickness of the plating varies from point-to-point as follows:

$$
t\left(x_{1}, x_{2}\right)=t_{a v r}+\zeta^{+}\left(x_{1}, x_{2}\right)+\zeta^{-}\left(x_{1}, x_{2}\right),
$$

where $\zeta^{+}\left(x_{1}, x_{2}\right)$ and $\zeta^{-}\left(x_{1}, x_{2}\right)$ are distance of points on top and bottom surfaces from average thickness plane (Fig. 1), respectively.

Since it is not feasible to measure all points, Monte Carlo simulation methodology was used to generate $\zeta^{-}$and $\zeta^{+}$. Among the various Monte Carlo simulation methods, the spectral representation method [10] is one of the most widely used today.

The power spectrum is another way of representing of sampling data series, $\zeta\left(x_{1}, x_{2}\right)$, based on wave number, $\left(k_{1}, k_{2}\right)$, which shows the contribution of different wave numbers in the series. Direct Fourier transform of original sampling points can be used to develop corresponding spectrum function.

Corrosion of structures shows a wide variation affected by a large number of factors, including the type of protection system, the age of the structure, location, temperature, humidity, and cleaning. One would expect to express a spectrum of the corroded surface as a function of above-mentioned variables, which are called external environmental variables. It is not feasible to express a spectrum of the corroded surface as a function of above-mentioned variables since so many sampling data is needed. The spectrum of the corroded surface is expressed as a function of geometry parameters which are called internal parameters and these parameters are related to environmental variables. Average thickness diminution and standard deviation of thickness are two geometry parameters of the corroded surface which are given for any environments. In order to express spectrum of corroded surface as a function of average and standard deviation of thickness diminution, following assumptions are made:

1. Thickness diminution is the average value of the sufficiently large number of thickness measurements.

2. The thickness of plate element is a stationary and ergodic random variable.

Based on these assumptions, one can apply type I asymptotic distribution rule to calculate extreme values of thickness diminution. Maximum thickness diminution is assumed as the extreme largest corrosion depth with a cumulative probability of $95 \%$, and minimum thickness diminution, as the smallest corrosion depth with a cumulative probability of $5 \%$. According to type I asymptotic distribution rule, these values are calculated as follows:

$$
\left\{\begin{array}{l}
\Delta t_{\max }=\Delta t_{a v r}+2.97 \sigma \\
\Delta t_{\min }=\Delta t_{a v r}-2.97 \sigma
\end{array}\right.
$$

where $\Delta t_{\text {avr }}$ is average thickness diminution and $\sigma$ is the standard deviation of thickness diminution (Fig. 2).

The Fast Fourier transform (FFT) technique is used to calculate two-dimensional spectrums of all sampling points from both sides of a corroded plate. Based on above assumptions and calculated spectrums, an expression for spectrum of corroded surface is proposed in the following form [5]:

$$
S(k)=\left\{\begin{array}{cc}
\frac{11.88 \alpha \beta \sigma}{k^{2}} \operatorname{Exp}\left[-\frac{2}{3}\left(\frac{\beta}{2.97 \sigma|k|}\right)^{3}\right] & \Delta t_{a v r} \leq 2.97 \sigma ; \\
\frac{\alpha \beta\left(\Delta t_{a v r}+2.97 \sigma\right)^{2}}{\Delta t_{a v r} k^{2}} \operatorname{Exp}\left[-\frac{2}{3}\left(\frac{\beta}{\Delta t_{a v r}|k|}\right)^{3}\right] & \Delta t_{a v r} \geq 2.97 \sigma,
\end{array}\right.
$$

where $k$ is wave number and $\alpha$ and $\beta$ are two constants which depend on corrosion condition and lie in the following range: $\alpha=0.01 \ldots 0.15, \beta=0.02 \ldots 0.15$. 


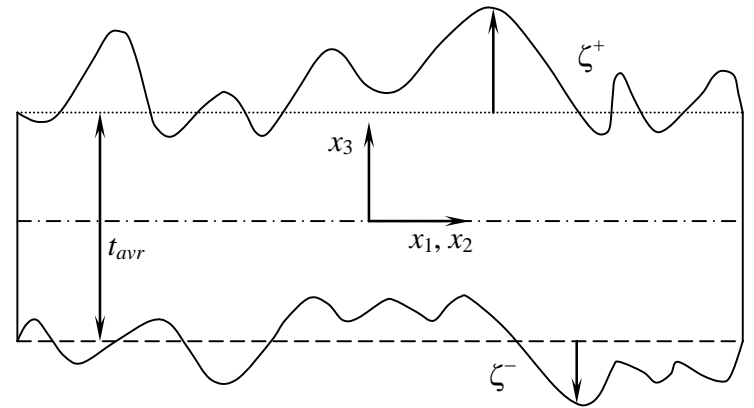

Fig. 1. Geometry of a plate with undulated surfaces

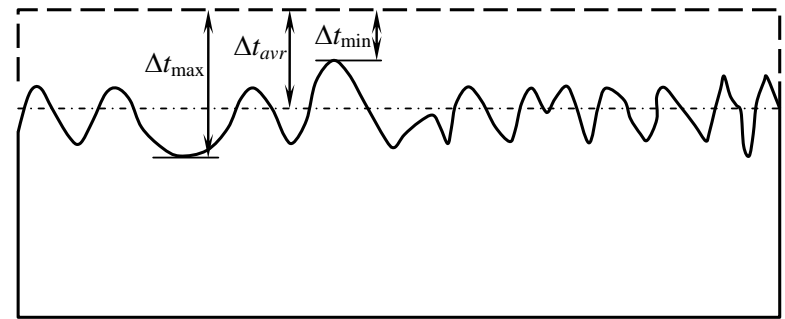

Fig. 2. Definition of $\Delta t_{\max }, \Delta t_{\text {avr }}$ and $\Delta t_{\min }$ for corroded surface

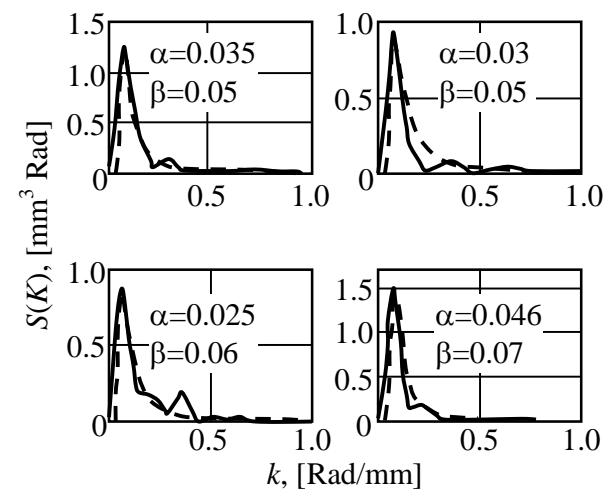

Fig. 3. Calculated and proposed spectrum of corroded surface: calkulated (-); proposed (- - -)

These two parameters are defined in a such way that statistical characteristic of the simulated surface has to be the same as the target surface. Fig. 3 shows some of the calculated spectrums from sampling points and proposed spectrums.

Isotropic spectrums in two directions are expressed by Eq. (3) since the stochastic characteristics of corroded surface in all directions are the same, where equivalent wave number is defined as follows:

$$
k_{e q}=\sqrt{k_{1}^{2}+k_{2}^{2}} .
$$

Three-dimensional geometry of corroded surface is simulated from the following equation:

$$
\begin{gathered}
\zeta\left(x_{1}, x_{2}\right)= \\
=\sqrt{2} \sum_{i=1}^{N_{1}} \sum_{j=1}^{N_{2}} \sqrt{2 S\left(k_{1 i}, k_{2 j}\right) \Delta k_{1} \Delta k_{2}}\left[\cos \left(k_{1 i} x_{1}+k_{2 j} x_{2}+\varphi_{1 i j}\right)+\right. \\
\left.+\cos \left(k_{1 i} x_{1}-k_{2 j} x_{2}+\varphi_{2 i j}\right)\right],
\end{gathered}
$$

where $N_{1}$ and $N_{2}$ are discretization numbers of spectrum in $x_{1}$ and $x_{2}$ directions respectively, $\varphi_{1 i j}$ and $\varphi_{2 i j}$ are random phase angles uniformly distributed between 0 and $2 \pi, \Delta k_{1}$ and $\Delta k_{2}$ are wave number increments in $x_{1}$ and $x_{2}$ directions respectively, and $k_{1 i}=i \Delta k_{1}$ and $k_{2 j}=j \Delta k_{2}$.

Elastic tripping analysis of flat bar stiffeners.

Stiffened plate could buckle in different modes, including flexural or torsional buckling of stiffeners, local buckling of flange or web of stiffeners and buckling of the plate between stiffeners. In torsional buckling or tripping, stiffener rotates as a rigid body about intersection point of the stiffener to attached plate. Tripping occurs in stiffeners with high flexural rigidity and low torsional rigidity. Euler stress for tripping of beams about center of torsion is calculated from following equation [11]:

$$
\sigma_{T E}=\frac{E I_{W}\left(\frac{\pi^{2}}{L^{2}}\right)+G J}{I_{0}},
$$

where $E$ is Young's modulus, $G$ is shear modulus, $I_{W}, J$ and $I_{0}$ are sectorial moment of inertia, St. Venant's moment of inertia, and polar moment of inertia about the center of torsion respectively, and $L$ is the length of the beam. The position of the center of torsion depends on boundary conditions of the beam. In stiffened panel, the center of torsion is located at the junction point of the stiffener to attached plate. Above cited parameters for FB stiffeners about this point are calculated as follows [12]:

$$
I_{W}=\frac{t_{W}^{3} h_{W}^{3}}{36} ;
$$




$$
\begin{gathered}
I_{0}=\frac{t_{W} h_{w}^{3}}{3} ; \\
J=\frac{h_{w} t_{w}^{3}}{3} .
\end{gathered}
$$

Elastic buckling assessment of corroded stiffeners with uneven thickness is only based on numerical analysis with FEM. A both-sided corroded plate with the same rough surfaces at each side is generated using shell elements with variable thickness at each node. A computer code in Fortran 90 is developed to generate irregular surfaces based on the mean and standard deviation of thickness reduction. Ordinates of this surface are deducted from an initial thickness of the plate and irregular thickness at each node is determined. In Fig. 4 finite elements model of FB with both sided corroded surfaces is shown.

Results and Discussion. In order to demonstrate the detrimental effect of corrosion with rough surfaces on elastic tripping stress, a series of FEM eigenvalue analyses are performed for different FB. The computer code ANSYS (version 5.6) has been used for this analysis. Both-sided corroded FB is modeled using shell element SHELL63. To enforce tripping about junction point of the web to attached plate and prevent flexural buckling, displacement in transverse and vertical directions at the baseline of the web are restrained. To ensure tripping of the beam without web distortion the rigid web is created. A uniformly distributed normal stress was applied over one end while holding the other end fixed.

Verification of finite elements model accuracy.

In order to check the accuracy of FE Models some preliminary un-corroded FB models are analyzed and compared with Eq. (6) (Table 1). As can be seen, very good agreements between FEM and Eq. (6) exist.

Corrosion conditions.

Guo et al. [13] have given equations to calculate the mean and standard deviation of corrosion wastage in deck plate of single hull tankers as a function of ships age based on measured data. Wang et al. [4] have given a mean and standard deviation of thickness reduction based on 110000 data measurements. Southwell et al. [14] have proposed the linear and bilinear model to estimate mean and standard deviation of corrosion wastages. Yamamato and Ikegami [15] have reported corrosion lost in bulk carriers based on data measurements. Guedes Soares et al. [16] have studied corrosion in different types of ship and have proposed some models for corrosion loss estimation. Five different corrosion conditions (Table 2) are considered and random irregular surface is generated for each condition.

Table 1

Table 2

Tripping Euler stress (MPa) of un-corroded Flat bars with different methods

\begin{tabular}{c|c|c}
\hline \multirow{2}{*}{$\begin{array}{c}\text { Flat-Bar } \\
(\mathrm{mm})\end{array}$} & \multicolumn{2}{|c}{ Euler Stress } \\
\cline { 2 - 3 }$(6)$ & FEM \\
\hline $50 \times 5$ & 793.51 & 790.29 \\
\hline $65 \times 6$ & 676.37 & 674.07 \\
\hline $75 \times 7$ & 691.69 & 689.50 \\
\hline $90 \times 8$ & 627.71 & 625.87 \\
\hline $100 \times 9$ & 643.75 & 641.94 \\
\hline $110 \times 11$ & 795.10 & 729.95 \\
\hline $120 \times 12$ & 795.48 & 793.40 \\
\hline $140 \times 13$ & 686.64 & 684.96 \\
\hline $160 \times 14$ & 610.46 & 609.07 \\
\hline $180 \times 15$ & 554.49 & 553.32 \\
\hline
\end{tabular}

Corrosion conditions considered in this work

\begin{tabular}{c|c}
\hline $\begin{array}{c}\text { Mean value } \\
(\mathrm{mm})\end{array}$ & $\begin{array}{c}\text { Standard deviation } \\
(\mathrm{mm})\end{array}$ \\
\hline 0.6 & 0.2 \\
\hline 1.0 & 0.23 \\
\hline 1.5 & 0.25 \\
\hline 1.75 & 0.28 \\
\hline 2.0 & 0.30 \\
\hline
\end{tabular}

Based on studies of Rahbar-Ranji and Zakeri [17], corrosion changes mechanical properties of steel plate, while Young's modulus and Poisson's ratio remain almost unchanged. Therefore, material is considered as mild steel with $E=206 \mathrm{GPa}$ and $v=0.3$, length of $3200 \mathrm{~mm}$ has been considered for stiffeners in this study. Statistical characteristics of generated surface for different corrosion conditions and FBs together with parameters $\alpha$ and $\beta$ are given in Table 3. 
Statistical characteristics of simulated surface for different FBs

\begin{tabular}{|c|c|c|c|c|c|c|c|c|c|}
\hline \multicolumn{2}{|c|}{ Target surface } & \multirow{2}{*}{ Type of FB } & \multicolumn{7}{|c|}{ Simulated surface } \\
\hline$\Delta t_{\mathrm{avr}}(\mathrm{mm})$ & $\sigma(\mathrm{mm})$ & & $\alpha$ & $\beta$ & $\Delta t_{\min }(\mathrm{mm})$ & $\Delta t_{a v r}(\mathrm{~mm})$ & $\Delta t_{\max }(\mathrm{mm})$ & CTP (mm) & $\sigma(\mathrm{mm})$ \\
\hline \multirow{9}{*}{0.6} & \multirow{9}{*}{0.2} & $50 \times 5$ & 0.035 & 0.03 & 0.01 & 0.61 & 1.33 & 1.33 & 0.20 \\
\hline & & $65 \times 6$ & 0.095 & 0.009 & 0.01 & 0.60 & 1.42 & 1.42 & 0.19 \\
\hline & & $75 \times 7$ & 0.032 & 0.030 & 0.01 & 0.60 & 1.43 & 1.42 & 0.20 \\
\hline & & $90 \times 8$ & 0.035 & 0.025 & 0.01 & 0.61 & 1.34 & 1.33 & 0.19 \\
\hline & & $100 \times 9$ & 0.025 & 0.036 & 0.01 & 0.61 & 1.39 & 1.38 & 0.20 \\
\hline & & $120 \times 12$ & 0.015 & 0.060 & 0.01 & 0.62 & 1.38 & 1.38 & 0.20 \\
\hline & & $140 \times 13$ & 0.030 & 0.030 & 0.01 & 0.61 & 1.32 & 1.31 & 0.20 \\
\hline & & $160 \times 14$ & 0.030 & 0.030 & 0.01 & 0.61 & 1.32 & 1.31 & 0.20 \\
\hline & & $180 \times 15$ & 0.030 & 0.030 & 0.01 & 0.61 & 1.33 & 1.32 & 0.20 \\
\hline \multirow{9}{*}{1.0} & \multirow{9}{*}{0.23} & $50 \times 5$ & 0.035 & 0.034 & 0.32 & 1.0 & 1.92 & 1.60 & 0.23 \\
\hline & & $65 \times 6$ & 0.038 & 0.030 & 0.32 & 1.01 & 1.92 & 1.60 & 0.23 \\
\hline & & $75 \times 7$ & 0.034 & 0.031 & 0.32 & 1.00 & 2.01 & 1.69 & 0.22 \\
\hline & & $90 \times 8$ & 0.050 & 0.020 & 0.32 & 1.00 & 1.95 & 1.64 & 0.22 \\
\hline & & $100 \times 9$ & 0.060 & 0.017 & 0.32 & 1.02 & 2.00 & 1.68 & 0.22 \\
\hline & & $120 \times 12$ & 0.014 & 0.070 & 0.32 & 1.02 & 1.86 & 1.54 & 0.23 \\
\hline & & $140 \times 13$ & 0.034 & 0.033 & 0.32 & 1.02 & 1.87 & 1.55 & 0.23 \\
\hline & & $160 \times 14$ & 0.035 & 0.030 & 0.32 & 1.00 & 1.84 & 1.53 & 0.23 \\
\hline & & $180 \times 15$ & 0.035 & 0.030 & 0.32 & 1.00 & 1.84 & 1.52 & 0.23 \\
\hline \multirow{9}{*}{1.5} & \multirow{9}{*}{0.25} & $50 \times 5$ & 0.054 & 0.024 & 0.75 & 1.50 & 2.50 & 1.74 & 0.25 \\
\hline & & $65 \times 6$ & 0.035 & 0.035 & 0.75 & 1.51 & 2.50 & 1.74 & 0.25 \\
\hline & & $75 \times 7$ & 0.056 & 0.020 & 0.75 & 1.52 & 2.56 & 1.80 & 0.24 \\
\hline & & $90 \times 8$ & 0.055 & 0.020 & 0.75 & 1.50 & 2.44 & 1.69 & 0.24 \\
\hline & & $100 \times 9$ & 0.035 & 0.032 & 0.75 & 1.53 & 2.45 & 1.69 & 0.25 \\
\hline & & $120 \times 12$ & 0.022 & 0.052 & 0.75 & 1.50 & 2.71 & 1.96 & 0.25 \\
\hline & & $140 \times 13$ & 0.036 & 0.033 & 0.75 & 1.49 & 2.47 & 1.71 & 0.25 \\
\hline & & $160 \times 14$ & 0.040 & 0.029 & 0.75 & 1.50 & 2.47 & 1.71 & 0.25 \\
\hline & & $180 \times 15$ & 0.036 & 0.030 & 0.75 & 1.50 & 2.34 & 1.59 & 0.25 \\
\hline \multirow{9}{*}{1.75} & \multirow{9}{*}{0.28} & $50 \times 5$ & 0.060 & 0.025 & 0.92 & 1.76 & 2.91 & 1.99 & 0.28 \\
\hline & & $65 \times 6$ & 0.015 & 0.090 & 0.92 & 1.77 & 2.75 & 1.83 & 0.27 \\
\hline & & $75 \times 7$ & 0.015 & 0.090 & 0.92 & 1.76 & 2.92 & 2.00 & 0.28 \\
\hline & & $90 \times 8$ & 0.030 & 0.052 & 0.92 & 1.78 & 2.87 & 1.95 & 0.28 \\
\hline & & $100 \times 9$ & 0.061 & 0.020 & 0.92 & 1.75 & 2.81 & 1.89 & 0.27 \\
\hline & & $120 \times 12$ & 0.036 & 0.036 & 0.92 & 1.76 & 3.12 & 2.20 & 0.28 \\
\hline & & $140 \times 13$ & 0.036 & 0.035 & 0.92 & 1.75 & 2.77 & 1.86 & 0.28 \\
\hline & & $160 \times 14$ & 0.038 & 0.035 & 0.92 & 1.74 & 1.76 & 1.85 & 0.28 \\
\hline & & $180 \times 15$ & 0.036 & 0.036 & 0.92 & 1.75 & 1.76 & 1.84 & 0.28 \\
\hline \multirow{9}{*}{2.0} & \multirow{9}{*}{0.3} & $50 \times 5$ & 0.080 & 0.020 & 1.11 & 2.01 & 3.23 & 2.12 & 0.3 \\
\hline & & $65 \times 6$ & 0.015 & 0.095 & 1.11 & 2.01 & 3.16 & 2.05 & 0.29 \\
\hline & & $75 \times 7$ & 0.015 & 0.095 & 1.11 & 2.00 & 3.23 & 2.12 & 0.30 \\
\hline & & $90 \times 8$ & 0.015 & 0.090 & 1.11 & 2.02 & 3.28 & 2.17 & 0.29 \\
\hline & & $100 \times 9$ & 0.043 & 0.031 & 1.11 & 2.03 & 3.20 & 2.09 & 0.30 \\
\hline & & $120 \times 12$ & 0.037 & 0.037 & 1.11 & 2.00 & 3.45 & 2.34 & 0.29 \\
\hline & & $140 \times 13$ & 0.046 & 0.030 & 1.11 & 2.01 & 3.11 & 2.00 & 0.30 \\
\hline & & $160 \times 14$ & 0.039 & 0.029 & 1.11 & 2.08 & 3.36 & 2.25 & 0.30 \\
\hline & & $180 \times 15$ & 0.041 & 0.035 & 1.11 & 2.00 & 3.09 & 1.98 & 0.30 \\
\hline
\end{tabular}

Euler tripping stress for FB with irregular thicknesses at each no is calculated using FEM and compared with Euler stress of FB with uniform thickness using Eq. (6). A reduction ratio for each case is defined as follows:

$$
R_{d}=\frac{\left(\sigma_{E T}\right)_{\text {Rough }}}{\left(\sigma_{E T}\right)_{\text {Flush }}}
$$


where $\sigma_{E T}$ is Euler stress for tripping mode of buckling. In Table 4 Euler tripping stresses and reduction ratio for FB with different corrosion conditions are quoted.

Table 4

Euler tripping stress of FBs with different corrosion conditions (MPa)

\begin{tabular}{|c|c|c|c|c|c|}
\hline \multicolumn{2}{|c|}{ Target surface } & \multirow{2}{*}{ Type of FB } & \multicolumn{3}{|c|}{ Euler tripping stress (MPa) } \\
\hline$\Delta t_{a v r}(\mathrm{~mm})$ & $\sigma(\mathrm{mm})$ & & Irregular thickness & Uniform thickness & Reduction ratio \\
\hline \multirow{9}{*}{0.6} & \multirow{9}{*}{0.2} & $50 \times 5$ & 590.72 & 601.39 & 0.982 \\
\hline & & $65 \times 6$ & 534.02 & 544.08 & 0.982 \\
\hline & & $75 \times 7$ & 568.45 & 572.04 & 0.994 \\
\hline & & $90 \times 8$ & 528.99 & 528.74 & 1.00 \\
\hline & & $100 \times 9$ & 556.11 & 556.23 & 1.00 \\
\hline & & $120 \times 12$ & 708.72 & 710.05 & 0.998 \\
\hline & & $140 \times 13$ & 616.85 & 622.39 & 0.991 \\
\hline & & $160 \times 14$ & 552.28 & 557.28 & 0.990 \\
\hline & & $180 \times 15$ & 504.17 & 508.74 & 0.991 \\
\hline \multirow{9}{*}{1.0} & \multirow{9}{*}{0.23} & $50 \times 5$ & 478.91 & 503.04 & 0.952 \\
\hline & & $65 \times 6$ & 456.05 & 462.69 & 0.986 \\
\hline & & $75 \times 7$ & 494.85 & 505.48 & 0.979 \\
\hline & & $90 \times 8$ & 473.15 & 475.45 & 0.995 \\
\hline & & $100 \times 9$ & 497.95 & 504.84 & 0.986 \\
\hline & & $120 \times 12$ & 660.35 & 658.32 & 1.003 \\
\hline & & $140 \times 13$ & 581.81 & 579.72 & 1.004 \\
\hline & & $160 \times 14$ & 524.27 & 522.77 & 1.003 \\
\hline & & $180 \times 15$ & 480.994 & 479.79 & 1.003 \\
\hline \multirow{9}{*}{1.5} & \multirow{9}{*}{0.25} & $50 \times 5$ & 359.12 & 384.27 & 0.935 \\
\hline & & $65 \times 6$ & 366.32 & 373.52 & 0.981 \\
\hline & & $75 \times 7$ & 411.04 & 419.79 & 0.979 \\
\hline & & $90 \times 8$ & 408.02 & 409.65 & 0.996 \\
\hline & & $100 \times 9$ & 437.17 & 436.90 & 1.00 \\
\hline & & $120 \times 12$ & 597.18 & 603.00 & 0.990 \\
\hline & & $140 \times 13$ & 528.29 & 533.35 & 0.990 \\
\hline & & $160 \times 14$ & 478.06 & 481.13 & 0.990 \\
\hline & & $180 \times 15$ & 444.12 & 448.16 & 0.990 \\
\hline \multirow{9}{*}{1.75} & \multirow{9}{*}{0.28} & $50 \times 5$ & 299.15 & 327.75 & 0.913 \\
\hline & & $65 \times 6$ & 317.46 & 330.62 & 0.960 \\
\hline & & $75 \times 7$ & 376.55 & 381.91 & 0.986 \\
\hline & & $90 \times 8$ & 375.70 & 376.76 & 0.997 \\
\hline & & $100 \times 9$ & 410.64 & 412.05 & 0.997 \\
\hline & & $120 \times 12$ & 566.77 & 573.26 & 0.989 \\
\hline & & $140 \times 13$ & 512.47 & 509.79 & 1.005 \\
\hline & & $160 \times 14$ & 457.90 & 462.05 & 0.990 \\
\hline & & $180 \times 15$ & 431.31 & 429.49 & 1.004 \\
\hline \multirow{9}{*}{2.0} & \multirow{9}{*}{0.30} & $50 \times 5$ & 249.01 & 278.57 & 0.894 \\
\hline & & $65 \times 6$ & 283.38 & 297.31 & 0.953 \\
\hline & & $75 \times 7$ & 340.82 & 346.65 & 0.983 \\
\hline & & $90 \times 8$ & 342.51 & 345.60 & 0.991 \\
\hline & & $100 \times 9$ & 382.56 & 382.95 & 1.00 \\
\hline & & $120 \times 12$ & 538.89 & 545.81 & 0.987 \\
\hline & & $140 \times 13$ & 489.65 & 486.76 & 1.006 \\
\hline & & $160 \times 14$ & 441.51 & 446.49 & 0.990 \\
\hline & & $180 \times 15$ & 408.92 & 410.14 & 0.997 \\
\hline
\end{tabular}


As can be seen, reduction factor can be as low as 0.894 . This indicates that by uniform thickness assumption, buckling strength of FB could be overestimated up to $11 \%$. Also in this table, the reduction ratio in some instances are equal or slightly bigger than one. This means that, depending on thickness distribution, buckling strength of FB with uniform thickness and irregular thickness could be the same. Oszvald and Dunai [18] have reported the same situation in buckling analysis of corroded angle elements. Due to randomness of thickness, which for some cases uniform thickness assumption yields, the interpretation could have the same results as an irregular surface assumption.

Fig. 4 shows the effect of standard deviation of thickness diminution (roughness of surface) on buckling strength reduction factor for FB $160 \times 14 \mathrm{~mm}$ with average thickness diminution of $1.0 \mathrm{~mm}$. As can be seen, standard deviation of thickness diminution has no influence on reduction factor of buckling strength.

Fig. 5 shows the effect of average thickness diminution for FB $160 \times 14 \mathrm{~mm}$ with a standard deviation of thickness diminution $0.25 \mathrm{~mm}$. As can be seen, average thickness diminution also has no influence on reduction factor.

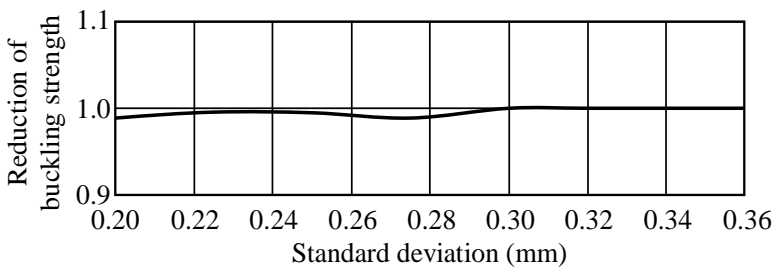

Fig. 4. Reduction of buckling strength factor for $F B$ $160 \times 14 \mathrm{~mm}$ with average thickness diminution $1.0 \mathrm{~mm}$

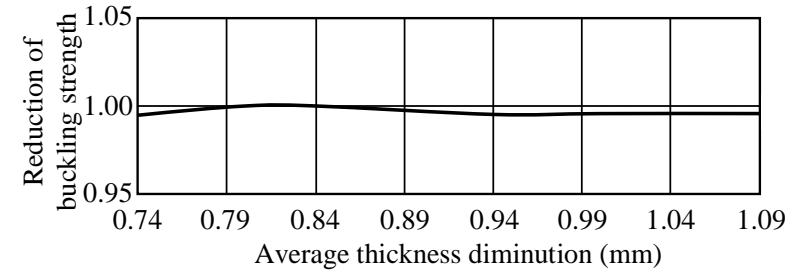

Fig. 5. Reduction ratio of buckling strength for $F B$ $160 \times 14 \mathrm{~mm}$ with standard deviation of thickness diminution $0.25 \mathrm{~mm}$

Fig. 6 and 7 show reduction ratios of buckling strength for FB $50 \times 5 \mathrm{~mm}$ and $160 \times 14 \mathrm{~mm}$ for different ratios of average thickness diminution to initial thickness (amount of corrosion loss). In these figures, standard deviation and average thickness diminution are taken as $0.30 \mathrm{~mm}$ and $2.0 \mathrm{~mm}$, and $0.275 \mathrm{~mm}$ and $1.0 \mathrm{~mm}$ respectively. As can be seen, the ratio of average thickness diminution to initial thickness has a weakening effect on reduction factor. The buckling strength reduction factor can become 0.89 in FB $50 \times 5 \mathrm{~mm}$ when the ratio of thickness diminution reaches 0.4 or in FB $160 \times 14 \mathrm{~mm}$ when the ratio of thickness diminution reaches 0.18 . In other words, buckling strength is overestimated by uniform thickness assumption up to $11 \%$ in FB $50 \times 5 \mathrm{~mm}$ when corrosion lost is $40 \%$, and in FB $160 \times 14 \mathrm{~mm}$ when corrosion loss is about $18 \%$.

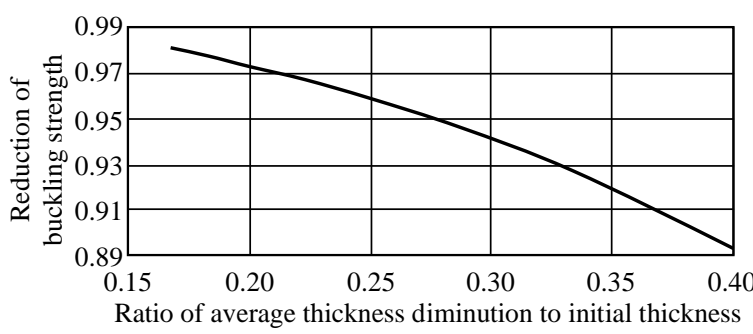

Fig. 6. Reduction factor of buckling strength for FB $50 \times 5 \mathrm{~mm}$ with average thickness diminution $2.0 \mathrm{~mm}$ and standard deviation $0.30 \mathrm{~mm}$

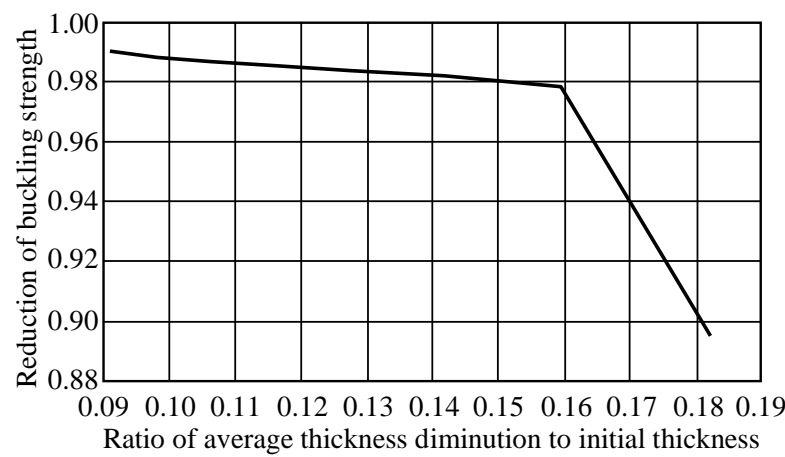

Fig. 7. Reduction factor of buckling strength for FB $160 \times 14$ with average thickness diminution $1.0 m m$ and standard deviation $0.275 \mathrm{~mm}$

Conclusions. There is a little study on strength of corroded plate with rough surface especially as a function of corrosion parameters. Eigenvalue analysis using FEM is used for tripping Euler stress analysis of corroded FB with both sided rough surface. A reduction factor is presented as a ratio of 
buckling strength of corroded FB with irregular thickness over buckling strength of corroded FB with uniform thickness. Influential parameters are studied and it was found that standard deviation and average thickness diminution have no effect on reduction factor of buckling strength. The ratio of average thickness diminution to initial thickness (amount of corrosion loss) has a weakening effect on reduction factor. Having reduction factor as a function of corrosion parameters, buckling strength of corroded FB could be evaluated easily as a function of the age of the structure. On the basis of considered set of FBs and tested corrosion assumptions this study reveals that considering uniform thickness, the buckling strength of FB is overestimated.

\section{Література}

1. Nakai, T. Effect of pitting corrosion on the ultimate strength of steel plates subjected to in-plane compression and bending / T. Nakai, H. Matsushita, N. Yamamoto // Journal of Marine Science and Technology. - 2006. - Vol. 11, Issue 1. - PP. 52 - 64.

2. Jiang, X. Ultimate capacity behavior of pitted mild steel plates under biaxial compression / X. Jiang, C. Guedes Soares // Proceedings of $30^{\text {th }}$ International Conference on Ocean, Offshore and Arctic Engineering (ASME 2011). — New York: ASME, 2011. — Vol. 2. — PP. 721 - 728.

3. Ultimate strength assessment of hull structural plate with pitting corrosion damnification under biaxial compression / Y. Huang, Y. Zhang, G. Liu, Q. Zhang // Ocean Engineering. — 2010. — Vol. 37, Issues 17-18. - PP. 1503 - 1512 .

4. Wang, G. Assessment of corrosion risks to aging ships using an experience database / G. Wang, J. Spencer, H. Sun // Journal of Offshore Mechanics and Arctic Engineering. — 2005. — Vol. 127, Issue 2. - PP. 167 - 174.

5. Rahbar-Ranji, A. (2001). Stress analysis of a randomly undulated plate due to corrosion in marine structures [Електронний ресурс] / A. Rahbar-Ranji. - Yokohama: Yokohama National University, 2001. Режим доступу: http://ci.nii.ac.jp/naid/500000211484 (Дата звернення: 11.08.2016).

6. Rahbar Ranji, A. Plastic collapse load of corroded steel plates / A. Rahbar Ranji // Sadhana. — 2012. Vol. 37, Issue 3. - PP. $341-349$.

7. Rahbar-Ranji, A. Ultimate strength of corroded steel plates with irregular surfaces under in-plane compression / A. Rahbar-Ranji // Ocean Engineering. - 2012. — Vol. 54. — PP. 261 - 269.

8. Rahbar Ranji, A. Buckling analysis of corroded angle beams with irregular random surfaces / A. Rahbar Ranji // Journal of Failure Analysis and Prevention. — 2016. — Vol. 16, Issue 5. — PP. 912 — 918.

9. Rahbar-Ranji, A. Elastic buckling strength of corroded steel plates / A. Rahbar-Ranji // Sadhana. 2013. - Vol. 38, Issue 1. - PP. 89 - 99.

10. Goda, Y. Numerical experiments on wave statistics with spectral simulation / Y. Goda // Report of the Port and Harbour Research Institute. - 1970. - Vol. 9, Issue 3. - PP. 3 - 57.

11. Timoshenko, S.P. Theory of Elastic Stability / S.P. Timoshenko, J.M. Gere. — 2nd Ed. — Mineola, N.Y.: Dover, 2009. - 541 p.

12. Hull Structural Design, Ships with Length 100 Metres and above [Електронний ресурс] / Det Norske Veritas // DNV Rules for Classification of Ships. - 2009. - Режим доступу: https://rules.dnvgl.com/servicedocuments/dnv (Дата звернення: 11.08.2016).

13. Time-varying ultimate strength of aging tanker deck plate considering corrosion effect / J. Guo, G. Wang, L. Ivanov, A.N. Perakis // Marine Structures. - 2008. — Vol. 21, Issue 4. - PP. 402 - 419.

14. Southwell, C.R. Estimating service life of steel in seawater / C.R. Southwell, J.D. Bultman, C.W. Hummer // B кн.: Seawater Corrosion Handbook / ed. by M. Schumacher. — New Jersey: Noyes Data Corporation, 1979. - PP. $374-387$.

15. Yamamoto, N. A study on the degradation of coating and corrosion of ship's hull based on the probabilistic approach / N. Yamamoto, K. Ikegami // Journal of Offshore Mechanics and Arctic Engineering. 1998. - Vol. 120, Issue 3. - PP. 121 - 128.

16. Guedes Soares, C. Effect of environmental factors on steel plate corrosion under marine immersion conditions / C. Guedes Soares, Y. Garbatov, A. Zayed // Corrosion Engineering, Science and Technology. - 2011. - Vol. 46, Issue 4. - PP. 524 - 541.

17. Rahbar Ranji, A. Mechanical properties and corrosion resistance of normal strength and high strength steels in chloride solution / A. Rahbar Ranji, A.H. Zakeri // Journal of Naval Architecture and Marine Engineering. - 2010. — Vol. 7, Issue 2. — PP. $94-100$. 
18. Oszvald, K. Effect of corrosion on the buckling of steel angle members - experimental study / K. Oszvald, L. Dunai // Periodica Polytechnica - Civil Engineering. — 2012. — Vol. 56, Issue 2. — PP. $175-183$.

\section{References}

1. Nakai, T., Matsushita, H., \& Yamamoto, N. (2006). Effect of pitting corrosion on the ultimate strength of steel plates subjected to in-plane compression and bending. Journal of Marine Science and Technology, 11(1), 52-64. DOI:10.1007/s00773-005-0203-4

2. Jiang, X., \& Guedes Soares, C. (2011). Ultimate capacity behavior of pitted mild steel plates under biaxial compression. In Proceedings of $30^{\text {th }}$ International Conference on Ocean, Offshore and Arctic Engineering (ASME 2011) (Vol. 2, pp. 721-728). New York: ASME. DOI:10.1115/OMAE2011-49980

3. Huang, Y., Zhang, Y., Liu, G., \& Zhang, Q. (2010). Ultimate strength assessment of hull structural plate with pitting corrosion damnification under biaxial compression. Ocean Engineering, 37(17-18), 15031512. DOI:10.1016/j.oceaneng.2010.08.001

4. Wang, G., Spencer, J., \& Sun, H. (2005). Assessment of corrosion risks to aging ships using an experience database. Journal of Offshore Mechanics and Arctic Engineering, 127(2), 167-174. DOI:10.1115/1.1894404

5. Rahbar-Ranji, A. (2001). Stress analysis of a randomly undulated plate due to corrosion in marine structures (PhD thesis, Yokohama National University). Yokohama: Yokohama National University.

6. Rahbar Ranji, A. (2012). Plastic collapse load of corroded steel plates. Sadhana, 37(3), 341-349. DOI:10.1007/s12046-012-0084-2

7. Rahbar-Ranji, A. (2012). Ultimate strength of corroded steel plates with irregular surfaces under inplane compression. Ocean Engineering, 54, 261-269. DOI:10.1016/j.oceaneng.2012.07.030

8. Rahbar Ranji, A. (2016). Buckling analysis of corroded angle beams with irregular random surfaces. Journal of Failure Analysis and Prevention, 16(5), 912-918. DOI:10.1007/s11668-016-0173-3

9. Rahbar-Ranji, A. (2013). Elastic buckling strength of corroded steel plates. Sadhana, 38(1), 89-99. DOI:10.1007/s12046-013-0116-6

10. Goda, Y. (1970). Numerical experiments on wave statistics with spectral simulation. Report of the Port and Harbour Research Institute, 9(3), 3-57.

11. Timoshenko, S.P., \& Gere, J.M. (2009). Theory of Elastic Stability ( $2^{\text {nd }}$ Ed.). Mineola, N.Y.: Dover.

12. Det Norske Veritas. (2009). Hull Structural Design, Ships with Length 100 Metres and Above. DNV Rules for Classification of Ships. Retrieved from https://rules.dnvgl.com/servicedocuments/dnv

13. Guo, J., Wang, G. Ivanov, L., \& Perakis, A.N. (2008). Time-varying ultimate strength of aging tanker deck plate considering corrosion effect. Marine Structures, 21(4), 402-419. DOI:10.1016/j.marstruc.2008.03.002

14. Southwell, C.R., Bultman, J.D., \& Hummer, C.W. (1979). Estimating service life of steel in seawater. In M. Schumacher (Ed.), Seawater Corrosion Handbook (pp. 374-387). New Jersey: Noyes Data Corporation.

15. Yamamoto, N., \& Ikegami, K. (1998). A study on the degradation of coating and corrosion of ship's hull based on the probabilistic approach. Journal of Offshore Mechanics and Arctic Engineering, 120(3), 121-128. DOI:10.1115/1.2829532

16. Guedes Soares, C., Garbatov, Y., Zayed, A. (2011). Effect of environmental factors on steel plate corrosion under marine immersion conditions. Corrosion Engineering, Science and Technology, 46(4), 524-541. DOI:10.1179/147842209X12559428167841

17. Rahbar Ranji, A., \& Zakeri, A.H. (2010). Mechanical properties and corrosion resistance of normal strength and high strength steels in chloride solution. Journal of Naval Architecture and Marine Engineering, 7(2), 94-100. DOI:10.3329/jname.v7i2.5309

18. Oszvald, K., \& Dunai, L. (2012). Effect of corrosion on the buckling of steel angle members - experimental study. Periodica Polytechnica - Civil Engineering, 56(2), 175-183. DOI:10.3311/pp.ci.2012-2.04

Received September 2, 2016

Accepted November 21, 2016 